\title{
Being and Becoming Woke in Teacher Education
}

\author{
Timothy Babulski \\ University of Southern Maine, United States of America \\ Email: timothy.babulski@maine.edu
}

\begin{abstract}
The role education plays in society has been contested in the United States since the inception of public education. Historically this contention has produced a delicate balance between promoting the social justice concerns of educating democratic citizens and the disciplinary concerns of individual intellectual development. Teacher preparation programs in American normal schools, colleges, and universities have traditionally struck a similar balance between theory and practice. In the past several decades, however, the rise of neoliberalism in American politics has shifted the balance away from equity, diversity, and inclusivity. The purpose of this study is to provide an account of the lived experiences of teacher candidates with the phenomena of being and becoming "woke" within a teacher education program that reflects neoliberal values but maintains a stated commitment to social justice. This study includes narrative vignettes that explore the phenomenality of "wokeness" as it manifests in the public-school environment and the teacher education program. It also addresses the effects of neoliberalism on teacher candidates' willingness and ability to take up social justice for themselves, their students, and society.
\end{abstract}

Keywords: neoliberalism, teacher education, social justice, higher education, public schools

\section{Framing the Phenomenon}

In the United States, teacher education has reached a pivotal moment. Devised for a monocultural agrarian society on the trailing cusp of the Enlightenment, American public education has routinely fallen short of meeting the needs of a student body whose diversity is increasingly intersectional and manifold (Taylor, 2010). Teacher education has traditionally sought to correct those deficiencies, but those who have tried to cultivate inclusivity and social justice have often been charged with relativism, revisionism, or a lack of rigor by those who prefer the singular "truth" of a disciplinary focus (pp. 77-82). Rather than addressing the pressing needs of a democratic society, the increased disciplinary isolation of the past several decades has left students emotionally and intellectually ill-prepared to cope with complexity, pluralism, and change. Along with disciplinary ethnocentrism, tribalism and corporatism, the commodification 
of knowledge and the commercialization of higher education has emerged as one of the most significant obstacles to a socially just education in the United States (Harkavy, 2006).

Teacher education has become woke. The term 'woke,' emerging from the twentieth century black American vernacular and popularized in William Melvin Kelley's 1962 New York Times essay "If You're Woke You Dig It," originally indicated an awareness of the specific injustices and abuses targeting the African American community. In the past several years, however, woke has been appropriated by various individuals, commercial entities, and institutions throughout American society as a generally antiracist or anti-oppressive stance. Within teacher preparation programs, woke has become shorthand for a set of dispositions concerning equity, diversity, and inclusivity, regardless of whether candidates engage in any form of anti-oppressive praxis to address specific inequities, promote diversity, or meaningfully include marginalized individuals and communities. Combined with the neoliberal orientation of American higher education, being woke has become a marketable attribute that teacher candidates either do or do not possess. As a teacher educator who has witnessed the neoliberal transformation of American public schools, I am interested in exploring the following question: How might being and becoming woke manifest in a neoliberal teacher education program that claims to value social justice?

\section{The Great American Model}

Education is the core of hegemony (Gramsci, 2011), and the contradictory nature of American society is reflected in a system of education that is simultaneously capitalist and anticapitalist, oppressive and liberatory, bounded by discourse, and grounded in lived experience. One possible way to resolve the contradictions of American public education, in favor of social justice, is to require teacher candidates to become woke to the power-knowledge relations that shaped their learning, as well as the continuing biases that define the limits of their pedagogical imaginary. Since the publication of Peters's (1982), A Neo-Liberal's Manifesto, state and federal governments have increasingly attempted to use market-based approaches to resolve the contradictions of education in favor of the capitalist hegemony.

Peters (1982) described a two-tier model of education divided along class lines. Upperclass students were educated at private schools and received instruction appropriate to their social standing and necessary to maintain their domination. The "lower orders," however, were kept in their place by failing public schools where they received a "bad education" (Peters, 1982). Unlike critical pedagogues who sought to uncover and disrupt the influence of capitalism on public education (e.g., Anyon, 1981; Freire, 1970/2000; Giroux, 1981), Peters embraced capitalism as the means to achieve a more just society. Soon after Peters (1982) called for districts to "fire [teachers] who can't or won't do the job" (para. 12). The National Commission on Excellence in Education (1983) published, A Nation at Risk, along with several other state and commission reports, these reports advanced the neoliberal agenda by promoting the belief that incompetent and malicious teachers were to blame for falling test scores (Baltodano, 2012).

Despite proof that the core "evidence" in A Nation at Risk was based on flawed statistics (Carson, Huelskamp, \& Woodall, 1993), proponents of the neoliberal approach devised statistical models to solve the problem of "falling" test scores indicated in the study. By promoting the belief that falling aggregate test scores were indicative of a systemic crisis of "failing schools," rather than the result of an increase in the percentage of students tested-a phenomenon known as Simpson's paradox - neoliberal reformers succeeded in causing several states to adopt Outcome- 
Based Education (OBE) (p. 272). Initially a project of conservative theorists in the 1970s, OBE utilized a structural, functionalist approach to curriculum that tended to reproduce inequitable social structures, reflect dominant political ideologies, and promote bourgeois economic interests (Capper \& Jamison, 1993). To gain acceptance from progressive educators, the version of OBE that was implemented adopted some of the rhetoric of prior social justice reforms as desirable outcomes. Despite "growing at an astounding rate" OBE was also geographically isolated in a handful of states - Kentucky, Minnesota, Michigan, and Washington - whose declining industrial economies and growing minority populations were most resonant with the dire warnings of $A$ Nation at Risk (Spady \& Marshall, 1991, p. 67). Without a federal framework, and attacked being both inadequately progressive and insufficiently conservative, OBE began to falter.

Rebranding efforts of OBE produced "Standards-Based Education" (SBE), eliminating the aspirational language of OBE, and refocusing reform efforts on measurable outcomes proved no more successful (Alderson \& Martin, 2007). The passage of the "No Child Left Behind Act" (2001) (NCLB), however, codified the neoliberal transformation of American public education. NCLB wedded the language of social justice to the mission of faulting teachers, closing schools, and promoting re-segregation via "school choice" (McClaren \& Farahmandpur, 2006). For example, while NCLB implemented long-sought anti-racist reforms such as detracking (e.g., Oakes, 1986a; 1986b) it also provided financial incentives for administrators to selectively place students where their scores could either be hidden in the statistics or clustered to improve aggregate results (Kalogrides \& Loeb, 2013). Coupled with the state-by-state approach that allowed for vast disparities in funding, curricula, teacher training, and how proficient was defined, NCLB was on a course to label all public schools in the United States as "failing" (Leyva, 2009). Neither the Obama administration's "Race to the Top" (RTT) program of 2009, nor the "Every Student Succeeds Act" of 2015 altered the status quo.

\section{The Teaching Order}

The neoliberal framework depends upon the existence of "lower orders" who receive a "bad education" from failing public schools; thus teacher candidates are likely to be woke to the idea of educational disparities even if they are personally ignorant of the specific causes and consequences social inequality. Teacher candidates may believe that closing gaps — such as those in achievement, opportunity, or technology-will eliminate the inequities that permeate society. At the same time, teacher candidates may find it challenging to become woke to the uncomfortable reality that neoliberalism is a project of white supremacism and a vehicle for class conflict. Their experiences in schools reinforce the idea that race and class - and not racism and classism-are predictors of educational outcomes and leave them unprepared to confront the socio-economic realities promulgated by an increasingly racially and economically segregated system.

Today in America, most early-career teacher candidates who enter the profession have never experienced a system that did not include standardized testing and neoliberal concepts of teacher accountability. The effect of this new population of teacher candidates on higher education teacher training programs is profound. Teacher candidates are more likely than their older peers to uncritically accept the use of value-added modeling to describe or predict teacher impacts as part of an "audit culture" that relies on market-based approaches and positions the dominant class as the "new oppressed" (Apple, 2006). Survivors of OBE and SBE, they have been coached in rhetorics of persistence and resilience to ignore structural and systemic issues and focus instead on measurable outcomes. Educated under the strictures NCLB and RTT, they have been taught to 
explicitly embrace the contradictions of asset mindedness, community embeddedness, political worldview, and critical consciousness (Pendakur, 2016). They have learned from the prevalence of standardized tests to dismember themselves and their peers into "dividuals" (Deleuze, 1992) who are not acknowledged as whole beings but are respected only for the particular assets, embodied-ness, and class consciousness valued by the bourgeoisie (p. 5).

\section{On Being and Becoming Woke}

To address the above social dismemberment, I focus on the following question: How might being and becoming woke manifest in a neoliberal teacher education program that claims to value social justice? I employ the methods of post-intentional phenomenology (Hofsess, 2016; Vagle, 2018) and auto-phenomenology (Babulski, 2017) to explore how the phenomenon manifests and appears in my experience, and the experience others, in the context of teacher education. As a phenomenon that has entered educational spaces from the broader American societal discourse of social justice in a similar manner to safe spaces, civility, and "white women's tears" (Accapadi, 2007, p. 210), woke-ness has both ontological and axiological components. Therefore, teacher educators must also be prepared to examine the moral and ethical implications of woke-impelled action and inaction and the effects of neoliberalism on shaping not only how we come to understand woke-ness, but how we apprehend our experience of the moral dimension of being and becoming woke in morally ambiguous contexts within education.

An integral part of post-intentional methodology is to understand the philosophical underpinnings that define our ontological approach and to make a philosophical claim (Vagle, 2018, pp. 142-144). In addition to leveraging the Deleuzoguattarian understanding of "Becoming" (Deleuze \& Guattari, 1987, pp. 237-239) in framing the phenomenon of woke-ness generally, this research also posits that being and becoming are ontologically distinct. Moran and Mooney (2002) specified that the phenomena of phenomenology include all forms of both positive and negative manifestations. How a phenomenon positively manifests - what it is - is therefore no more important than how it relates to other phenomena - what it is not. If the phenomenon of being woke occludes, obscures, denies, or even bears witness to becoming woke, it is therefore possible that being and becoming woke are cognizable as ontologically separate, albeit epistemologically related phenomena. In framing the phenomenon, I have already begun to separate the being and becoming of woke-ness.

Being and becoming also has resonance with the tenets of neoliberalism. Despite efforts to rehabilitate the term and take up of a Heraclitan mantle of change (see Pirie, 2017), neoliberalism is a totalizing doctrine that is ontologically flat - all things, human and non-human belong to the market - and ontologically tiny and static - nothing non-economic exists. Deleuzaoguattarian Becoming is also ontologically flat - rejecting both the Hegelian linearity of historical progress and arboresque constructions of knowledge - but, unlike neoliberal being, is ontologically expansive, complex, and unsettled. It does not privilege a single way of knowing the world but recognizes the flux and flow of the de- and re-territorializing self ever in relation to experience (Deleuze \& Guattari, 1987). Becoming in the sense of not-yet being, therefore, is a form of unbeing that must always be distinct from being. To illustrate how being and becoming woke operate and remain distinct within the neoliberal context of teacher preparation, I have divided this paper into a pair of vignettes and sections, analyzing the phenomenological implications and neoliberal associations of each narrative. I derived the story data from a combination of semi-structured interviews, formal observations, and personal memoranda of teacher candidates, I taught and 
supervised during the 2017-2018 academic year, who expressed interest in exploring the social justice implications of their student teaching experiences. I have changed the names of teacher candidates to maintain anonymity and confidentiality. Following Doyle (2007), I allowed the teacher candidates that impelled my awareness of the phenomena access to the synthesized data and constructed narratives and incorporated their feedback into the final product.

In the following two vignettes, I explore the lived experiences of Robin and Melissa in being and becoming woke, as well as my entanglement in the phenomena as a supervisor of teacher candidates. My role as a low-level officer of the university, and as a point-of-contact for teacher candidates, entail responsibilities to represent the institution and its neoliberal tenets and to advocate for teacher candidates whose needs are not served by a market-based approach to teacher education.

\section{Safe Spaces and More Important Things}

It is a Tuesday morning in March in the upper Midwest of the United States, beautiful but brutally cold. I awakened angry, but that is somewhat unsurprising as I went to sleep upset.

Yesterday, a teacher candidate, Robin, approached the lecturer in charge of the student teaching seminar about an hour before the session began. Robin did not identify with any gender and had expressed a preference for non-binary pronouns that they felt were being ignored by their peers, members of the faculty, and their cooperating teacher. Robin informed the lecturer that they thought the university and the program area had not met their social and emotional needs. As I would later verify with my assigned teacher candidates, they had also been repeatedly bullied by several individuals within the cohort over social media who referred to Robin's expression of gender as "offensive to women" because "he was a man pretending not to be a man to get sympathy." Robin revealed that they were tired of having to explain to their bullies that genitalia does not determine gender. They were exhausted from having to teach allies how to be allies who understood, for example, the difference between non-binary and genderqueer or between gender and sexuality. The lecturer listened to Robin and, several minutes later, reported the substance of Robin's grievance.

"What," the lecturer asked, "should we do about Robin?"

On reflection, I suppose that is what first lit the fuse. The lecturer had not asked what we should do about the bullying, Robin's peers, or those who misused their authority. She rejected Robin's critique of their cooperating teacher, an out gay man, because he was "good at that kind of thing." She had, she said, assigned Robin to that teacher for that reason. Similarly, she dismissed Robin's perception of institutional ambivalence and faculty incompetence because "we already talked about all of this in the Fall." To her credit, the lecturer expressed concern that Robin felt bullied, but she also claimed that "he," referring to them with the wrong pronoun, was also "just too sensitive."

"We can give him a safe space tonight, but he's just going to have to get tougher," she said.

After greeting the gathered teacher candidates and reflecting on the cold weather, she explained the purpose of "taking time out from our busy agenda" to talk about identity was so that everyone could think about their identities "as individuals, artists, and teachers" and reflect on the "many hats" that teachers are required to wear. As we moved our chairs into a rough circle around the perimeter of the room, the lecturer asked one of the candidates to close the door because we were "taking up such a sensitive subject."

By this point, I could already feel a twitching in my cheek. 
For twenty minutes, those who should have had the most to say were silent. I could feel my attention waver with each empty platitude. My hands rhythmically clenched and unclenched. There was a tightness in my jaw and heat on my cheeks. My ears were so hot that I was sure everyone could see them glowing red. At the moment, it seemed that my anger had been welling up since the lecturer first asked for the door to be shut.

"I'm sorry," I said, interrupting yet another monologue on having students connect with us as artists, "I think we're missing the point..."

As I spoke - too loudly, I thought, with my emotions visible to everyone in the room-I tried to bring something of my own experience to them. I shared how my experiences othered me and left me vulnerable to the agents of the State. Had I let my employers know about my sexual orientation or religious beliefs, I would have never been hired. Had I let my students know, or even made it possible for them to find out on social media or through an indiscreet comment, I would have been fired. As a teacher in a right-to-work state, my termination could happen within hours of bringing my identity into my classroom or be delayed indefinitely until the first parent complained that they did not want a deviant to teach their child. Whether it took hours or weeks, voicing my identity would have cost me my job.

I told the cohort that I did not see this as the consequence of the individual students, parents, administrators, or fellow teachers trying to maintain privilege and power. Those that would enact oppression often fervently believed that were enacting normalcy. It did not take agents of oppression to enact oppression. Instead, it required only complicity in the form of silence or inaction to normalize being white, middle-class, heterosexual, cis-gendered, male, and Christian.

"Unless we say something, can we ever expect any different?" I asked. Into the silence that followed that question, Robin finally spoke. They agreed with me that it was not about people trying to be cruel, but about others' discomfort with a world that is less normal than they would presume it to be. They thanked the lecturer and said they were keenly aware that she had made an effort to include them and honor their experience, but they felt they still could not bring their own identity forward. They were leery, they said, of taking the time that was set aside for the whole cohort and using it to discuss what they saw as their difficulties. We sometimes get the sense that others are listening, not to what we say, but for a pause into which they can insert themselves. During my denunciation and Robin's enunciation, however, the texture of the surrounding silence was more profound and would have lingered well-past Robin's final words.

Rather than allow a pause for thought and time for Robin's ideas to incubate, the lecturer immediately intervened to end the discussion. It seemed that time had expired, and other matters required the cohort's attention. Robin seemed unsurprised when the lecturer stated that test-scores were more important than talking about inclusion and that it was time to move on to "more important things."

\section{Robin: Phenomenological Analysis}

The textuality of this vignette allows me to recognize that I have become increasingly indignant over the past several years, yet I was not aware of how profoundly incensed I was becoming until I could no longer contain it. I had known that the lecturer had a predilection to favor "civility" and "decorum" over engagement. I was not surprised by Robin's insistence that teacher candidates should always be "professional" in their online reflections and classroom interactions, even when professionalism meant ignoring issues that they were not positioned to solve. I could conceive how repeating the dictum to "be polite" might convince teacher candidates 
to perform contentment rather than to affectively engage with teaching even as they work through personal trauma, rail against the violence inherent in the system, and struggle to deal with the trauma of others. I was woke to all of this, but only in the abstract.

When I saw these ideas enacted, however, I experienced woke-ness as a becoming that manifested in opposition to my already being woke. As a teacher, I experienced it much as I conceive of the difference between knowledge and understanding. Knowledge is passive, inherited, or assumed. Understanding, however, is tied to experience either intimately lived or empathically felt. Had the lecturer constructed the safe space more purposefully, I do not doubt that our candidates would have emerged with more knowledge at least regarding the issues that Robin and people like them face when addressing the normative function of education in neoliberal contexts. Had she constructed the safe space to be less normatively civil and, paradoxically, safer for alterity, our candidates might have gained understanding through processing their own experiences and empathizing with the experiences of others.

At moments like this, torn between pedagogy and desire, I am most conscious of my body. I wanted to have no voice in the discussion and listen to our teacher candidates take on risk, difficulty, and possible controversy. I thought it was vital that they have ownership of the issue and exercise control of how it is taken up. There was, I thought, no connection between what the lecturer had intended and what candidates voiced. It was a pedagogical space that left no room for alterity. She was asking the few of our candidates who had experienced being othered to actively other themselves for the edification of the many and seemed unaware of how their silent nonparticipation was passively othering them.

As a white, cis-gendered man and teacher, I was automatically an agent of the unitary plurality of teaching, but I was also mindful of the Foucauldian precept that "resistance is never in a position of exteriority in relation to power" (Foucault, 1990, p. 95). To resist the neoliberal appropriation of anti-oppressive discourses, I had to be what Deleuze and Guattari (1987) termed a "Sorcerer" (p. 243), anomalous, an Outsider at the borderline between the lecturer and the candidates. I was their ally, not their friend or equal. I could not provide those that had never been Othered with an experience of being Othered, but I could perhaps impel them into becoming woke through empathy.

\section{Robin: Neoliberal Associations}

The lecturer deserves some amount of credit for creating a safe space in which both being and becoming woke proved possible. She had not established the guidelines or ground rules as recommended by Arao and Clemens (2013); thus she has failed to indicate to the teacher candidates which discourses they might safely engage in or whose safety the space served. Unless the facilitators specifically designate the space safe for the authentic experience of alterity, safe spaces require participants to be Othered or assimilated in exchange for being heard (Ellsworth, 1992). Even being listened to is not enough; safe spaces cannot empower students so long as they rest on the presumption that oppression and anti-oppressive efforts are agentic and position students "as individuals with only the most abstract of relations to concrete contexts of struggle" (Ellsworth, 1989, p. 311). The safe space that the lecturer established thus manifested as a marketplace of ideas (e.g., Blocher, 2008).

In this safe space-cum-marketplace, Robin received social capital in exchange for selling their story. The amount of social capital they received is an indicator of the relative virtue of their position; if Robin's peers valued their story, they would become virtuous. They would also be able 
to use the accumulated social capital to offset any perceived defect or deficiency of character. For Robin's experience to be valued and cause an accretion of virtue, Robin would have to overcome the tendency of the market to prefer homogeneity. In a marketplace of ideas, those who would use disruptive means or promote disruptive ideas must "overcome both a socialization system that predisposes the public against unconventional perspectives, as well as a negative response to [their] message's packaging" (Ingber, 1984, p. 48). By leveraging the characteristics of a marketplace and attempting to minimize the "disruptive means" that Robin might have otherwise used, the lecturer created a space where those who most benefited from the status quo would be safe from hearing anything that might upset them.

By also tacitly promoting the belief that preparing teacher candidates for a standardized teacher performance assessment was a "more important thing" than causing teacher candidates to confront discrimination, she was drawing on the discourse of what $\mathrm{Au}$ (2016) called "Meritocracy 2.0" (p. 40). Echoing Hursh's (2008) assessment that standardized testing reflects a greater faith in the market than in teachers and students, $\mathrm{Au}$ (2016) noted how test scores define success and failure and are "used to justify neoliberal conceptions of individualist educational attainment and the denial of structural inequalities" (p. 42). While Au (2016) identifies the testing regime as a structural feature of the racial project of neoliberal multiculturalism, the elevation of test preparation in this instance also demonstrates neoliberal opposition to and diminution of all forms of alterity as part of a broader project of white supremacism and cultural genocide. The use of a safe space within the confined space of the classroom and the strictly controlled schedule established a paradigm of isolation. As Robin's request for a safe space ironically demonstrated, they knew that all other times and spaces were intrinsically unsafe to express their alterity or share their lived experiences. It was possible in that space for the lecturer to teach teacher candidates to value alterity as a scarce commodity that, if not protected, would be tragically lost (Baudrillard \& Guillaume, 2008). By establishing that test preparation as one of several "more important things," however, those who possessed alterity were being encouraged not to express it. Unless the lecturer, as the owner of the space, made clear that becoming woke to or possessing alterity conferred more social capital than those other things, those who were the most different would be those with the least social capital to spend. By merely being Other, Robin exposed the transactional nature of neoliberal discourses of social justice. It was another teacher candidate, Melissa, whose experiences demonstrated the disconnect between the neoliberal discourse of individual accountability and the institutional commitment to social justice. Turning to her story also reveals the neoliberal preference for being over becoming woke.

\section{Intersectionality and Shutting Up}

Melissa had a history.

Always reserved, she seemed to retreat into herself whenever things got complicated. I had seen it happen before: in class, when her classmates said something she profoundly disagreed with, she had lapsed into a silence that took her several weeks to break. By the time spring semester rolled around, there were a few teacher candidates she would not speak to at all. Then, a few weeks into her first placement, there was an incident.

Her cooperating teacher, a white man several decades her senior had asserted his authority in a troubling manner, seizing intellectual ownership of her lesson plans about underrepresented artists of color. On his own, he had negotiated with another teacher about how Melissa would implement the lessons and what changes she needed to make before teaching them. Melissa didn't 
tell anyone right away, waiting until the end of the week to write about what had happened in her student teaching journal. She was more expressive in prose than I had ever seen her be in person. When I read her account, I could imagine her pacing back and forth, gesticulating wildly as embarrassment colored her cheeks and ears, and her voice rose in anger. I wondered if Melissa would be as passionate in person as she was on the page and what we could do to help her deal with a mentor that had fallen short.

I went to campus over an hour early that Monday, and, as soon as the lecturer had a free moment, I asked what she thought about Melissa's journal. Rather than answering, the lecturer asked me to tell her "what about it" that I found troubling. Having listened to me relate only the most cursory version of the narrative, the lecturer pronounced that Melissa had experienced "classic sexism" and asked how I intended "to handle it." I was momentarily stunned. I had planned to ask the lecturer what we should do about the cooperating teacher and whether Melissa's experience was worth bringing to the attention of the whole class. I had not reflected on what I might do in the small group setting because so much depended on what Melissa had experienced since and what she chose to share.

The lecturer preferred that I take a more didactic approach and coach Melissa by offering her several options: Melissa could ignore it and "let it slide," she could confront her cooperating teacher directly, or she could try to call it out but from a position of shared humanity. The lecturer then offered to step in and "handle it" for me so that I wouldn't come across as "mansplaining."

I have helped many teacher candidates through troubling encounters before, but I remember feeling the lecturer's gaze on the back of my head. I was acutely conscious of her proximity to our table. I hoped that my students could not see the annoyance on my face as I pushed being watched to the back of my mind and introduced the topics for discussion. I did as the lecturer had instructed me.

"So," I said, "I was disturbed to read about what happened last week. It sounded pretty sexist to me."

Always somewhat reserved, Melissa seemed disinclined to speak. When she spoke, she said that she had felt powerless at that moment but, now that the moment had passed, was reluctant to say anything else about it. Despite my reluctance to do so, I informed Melissa about the range of options available to her.

It was when another white female candidate, Bethany, said, "I think it's complete bullshit," then the lecturer stepped towards us, openly paying attention.

"No man," Bethany said, "should ever tell a woman what to do about sexism," then a little more quietly as if sharing a secret, "They should just shut the fuck up."

The lecturer smiled and nodded.

So, being in no position to argue, I did precisely that.

It was a few weeks later when Melissa and I both had the chance to revisit the decisions that directed our silence and inaction. By that time, Melissa had transitioned to another placement at a much more racially, linguistically, and socio-economically diverse school. She had renewed her interest in designing curricula that would expose students to traditionally underrepresented artists of color, help them discover how artists used their art to advocate for social change, and take up advocacy through their artwork on issues of their choosing.

One student, a young black woman, chose to react to a series of Twitter (a social network platform designed for micro blogging) tweets that disparaged Beyoncé and Rhianna (two popular black female musicians). One tweet, for example, contained four images of Rihanna photoshopped with white skin and the caption, "Rihanna en blanche, elle est magnifique, je suis amoureuse"- 
Rihanna is white, she is beautiful, I am in love. In keeping with the assignment, the student chose to create an illustration that employed the iconography and æsthetics of twitter to show tweets with slogans from the Black is Beautiful movement. In the center of her composition, she depicted a tweet with the words, "Rihanna wouldn't be beautiful if she was White."

The cooperating teacher objected that this - a statement of pride in being black - was racist against white women and was personally offended by it.

The young woman responded, "I don't understand."

The teacher then accused the student of being racist for creating the image and was old enough to understand that "this is basically saying that white women can't be beautiful." The cooperating teacher informed the student that she intended to censor the artwork and that the student would not receive a grade until "she fixed it" to the cooperating teacher's satisfaction.

The young woman again responded, "I don't understand, Miss [Melissa] said it was okay."

The cooperating teacher did not respond, and Melissa chose not to intervene, believing that intervention would only increase tensions between student and teacher. Even when she attempted to clarify what the cooperating teacher had found to be problematic, Melissa encountered resistance. Melissa wrote that she had "no idea how to further interact with this student's project" or how to "ffix it' when the fixing that's needed is a reality check on white fragility and a detrimental insecurity."

I attempted to address the cooperating teacher's troubling behaviors and views that were at the center of the issue but also to caution Melissa not to essentialize students, racism, or antiracist advocacy. I invited her to share her story during supervisor time, but I hoped that I could inveigle the lecturer into convening a whole-cohort discussion around our responses to race and racism. I was dismayed, however, to discover that the lecturer was not troubled by the interaction between student and teacher. Instead, the lecturer was disturbed about the unknown someone who had advised Melissa to file a report and claimed that Melissa "is just one of those people who's not going to be happy unless she's stirring something up." When I pressed the lecturer, she sided with the cooperating teacher, agreeing with the view that the student's artwork was "obviously racist against white women." The lecturer told me not to do anything about it because the cooperating teacher had already exercised her authority to resolve the situation.

While the lecturer was not compelled to act, however, I was.

I visited Melissa and her cooperating teacher at $2 \mathrm{pm}$ on the following day.

I asked Melissa to introduce me to the student and to allow me to view the artwork. I could tell from the pasted-on layers of paper that the artwork I saw was not the student's first attempt to mollify the cooperating teacher. I learned from her that the teacher told her that her first proposed alternative, "Rihanna is beautiful because she's Black," was still racist towards white women. Having already modified her artwork, she was forced to alter it again to say only "Rihanna is beautiful" without any reference to race at all. Her censorship was sloppy with the edited words written on separate pieces of paper and pasted over the original. It would have earned a middling grade had Melissa assessed aesthetics and technique. Melissa had designed her assessment around the connection students made to an issue of social justice and the potential of their artwork to raise critical consciousness, however. By that metric, the original project had succeeded where the edited one had not, and the clumsy attempt at censorship reduced both the apparent level of craftsmanship and its potential impact.

When I pulled aside the cooperating teacher at the end of the school day, she informed me that the student in question was "just one of those students" who does not do any work and who was "only trying to get attention" by being as outrageous as possible. She assured me that the low 
quality of the final work showed that the student had not taken the assignment or her anti-racist stance seriously.

\section{Melissa: Phenomenological Analysis}

After the first incident, it would have been easy to see Melissa as another teacher candidate who allowed being woke to curtail acting against oppression rather than someone whose inaction was a calculated response to becoming woke. I had seen similar scenarios play out with other candidates and in different contexts. I believed that there was a confluence of factors relating to Melissa's intersections of identity. The inherent sexism was clear, but it was also possible that the cooperating teacher was inappropriately reacting to her age and lack of experience, her racial identity, her social class, or a perceived lack of rigor in the lesson plans. Because of the limited and highly structured nature of our in-class interaction and the constrained nature of her response, I could not be confident whether Melissa perceived the events as singularly sexist in the mode of the lecturer or was becoming aware of intersectionality.

After the second incident, it seems that Melissa was experiencing being and becoming woke simultaneously as distinct, but situationally related phenomena. Melissa did not require the misguided chauvinism of a cooperating teacher to convince her that sexism existed or demonstrate how it operated. Similarly, she did not need her next cooperating teacher to act to understand that many would eschew the racist label and yet enact racism. At the same time, Melissa seemed to become woke to the intersectionality of racism, classism, and sexism in her first placement. In our interaction with Bethany and the rest of the supervisory group, Melissa became woke to how supposed allies might weaponize her experience to score points. In her second placement, she became woke to the unfortunate tendency of some women to use "white women's tears" (Accapadi, 2007, p. 210) to undermine the anti-oppressive efforts of women of color. Melissa also experienced both being and becoming woke differently from Robin, Bethany, or the lecturer. For her, the emotional interaction was no less immediate, but whereas Robin seemed to despair and Bethany to become angry, Melissa seemed confused.

Her confusion stands in contrast to the manifestation of being woke apparent in Bethany, the lecturer, and Melissa's cooperating teachers. In each of those cases, being woke had prevented becoming woke. Her first cooperating teacher, being woke to racism, felt privileged enough to act in an overtly sexist and covertly racist way. Bethany, woke to sexism, could not resist silencing me when I was making the space safe for Melissa should she have wished to utilize it. Because the lecturer was woke to sexism, she directed me to use supervisor time to take on sexism in a way that I worried was inherently sexist.

Like Melissa, I was initially confused by the cooperating teacher's reaction. Unlike Melissa, however, I believed the cooperating teacher was woke, albeit experiencing wokeness as being. The cooperating teacher may well have been correct that her student rarely attended class, never did any work, and selfishly used disruption to get attention. Already an imperfect messenger, by establishing the relative values of whiteness and blackness to be the opposite of those promoted in a racist tweet, the student had crafted an expression that, understood in the neoliberal context of public education, was also racist. Thus, Melissa's and her cooperating teacher's lived experiences of being and becoming woke conflicted. To determine whether being and becoming woke is one phenomenon with multiple manifestations or are separate phenomena, we can look at each participant's relation to the context of neoliberalism. 
Melissa was an outsider in her placement, attempting to apply the theories of progressive and critical teaching at a school that had adopted the tenets of the marketplace in a way that could disrupt the conventional thinking on issues of the day. Her cooperating teacher, however, sought to honor social justice within the system in a way that would preserve the functioning of the system and her place within it. It is possible that context controlled for the different manifestation of wokeness and that the cooperating teacher's actions and the lecturer's dismissal of Melissa's concerns demonstrate that being and becoming woke as a single phenomenon. I will take Melissa at her word, however. Having neared the end of her second placement, she was neither an outsider to that particular classroom or the broader context of public schooling. Indeed, she had designed a project that inspired the student to attend class regularly, complete her work promptly, and use the disruption of a racist meme to facilitate an anti-racist conversation within the expected structures and limits of school. Melissa's embodiment of and movement between being and becoming woke suggests that the contours of both phenomena are as yet unmapped, are multi-stable, or inherently unstable.

\section{Melissa: Neoliberal Associations}

Regardless of how being and becoming woke manifest in Melissa's experience, there were also a series of unvoiced economic calculations at play. When Melissa's first cooperating teacher enacted oppression, the lecturer opposed my intervention because my maleness conferred a negative value that could not be entirely offset by the positive value of my experience. To Bethany, gender was such a large deficit that "no man" could possess any combination of skills, attributes, or identity sufficient to offset it. The lecturer's tacit approval of Bethany's gendered tactic also illustrates the neoliberal preference for individual over collective action and offers further confirmation of how neoliberal multiculturalism employs the language of "asset mindedness" to assign social or cultural value to others as dividuals (see Deleuze, 1992). Melissa's second cooperating teacher's preference for an easily consumed product, rather than something that might challenge preconceptions, demonstrates a similar calculation. The cost of censoring a student was entirely offset by the value of not upsetting a white woman, even at the added cost of exposing her fragility. In each case, the individuals enacting oppression held a deficit model of Melissa and her students while claiming to be asset minded.

According to Pendakur (2016), "deficit models do not place the responsibility for change and adaptation on the institution or the system but rather on the shoulders of the marginalized" ( $p$. 114). Indeed, through the neoliberal appropriation of anti-sexist efforts and the asset minded marketization of identity, the lecturer had not placed responsibility for changing the sexist culture of the school had on the offender, the institution, or the marginalized collectively but on the shoulders of one woman. How Melissa would deal with her cooperating teacher's biases would indicate her value as a potential asset to schools and the importance of her virtues as assets to her. If the lecturer or Bethany could handle the situation more adroitly than Melissa, they would be economically and morally superior. In this way, the neoliberal reliance on the competitive individualism of meritocracy "functions as an ideological myth to obscure economic and social inequalities and the role it plays in curtailing social equality" (Littler, 2013, p. 55).

In the neoliberal context, collective intentionality and action are compromised and constrained by the facts, rules, and norms of institutional reality that "entitle both the holder of the role and interactors to certain actions but not to others" (Rakoczy, 2017, p. 413). Through labeling and sorting, schools generate facts about individuals that become markers of identity. The greatest 
danger is not that those who have most successfully learned to follow the rules will come to enforce them, however. Instead, it is that "teacher candidate" and "teacher" have become just another marker of identity to be valued, or not, by the dictates of a marketplace that operates under the aegis of neutrality while it indoctrinates the next generation with the tenets of neoliberalism.

\section{Conclusions}

Students in a neoliberal teacher preparation program, future teacher candidates, are consumers of an educational product that, once attained, is expected to confer particular social and economic value. In neoliberal multiculturalism, being woke to racism, ageism, sexism, tokenism, and the politics of representation is perfectly acceptable because it responsibilizes personal awareness and precludes collective action. Being woke to any particular form of Oppression carries a social value that can be associated with candidates as dividuals. Outrage might be considered a scarce commodity in the marketplace of ideas; possessing and using it establishes a marker of individual value that simultaneously diminishes the amount of outrage available for others and limits the utility of that outrage. Neoliberalism cannot long tolerate becoming woke, however, because in all the manifestations that I have experienced, becoming woke ultimately invokes empathy and impels cooperative and collective action.

I have never enjoyed the indignation, disappointment, and despair that characterizes the initial manifestation of becoming woke, but I can no longer abide by the false certainty of being woke. As I have crafted this text I have returned to my experiences and those of my teacher candidates, experiencing anew the shock and turmoil of becoming woke in a world that is not yet as just as it should, and must, become. If I am to keep becoming, I may still be angry from time to time, but I will also be hopeful that there will be those who will become woke with me-and keep becoming.

\section{References}

Accapadi, M. M. (2007). When white women cry: How white women's tears oppress women of color. The College Student Affairs Journal, 26(2), 208-215.

Alderson, A., \& Martin, M. (2007). Outcomes based education: Where has it come from and where is it going? Issues in Educational Research, 17(2), 161-182.

Anyon, J. (1981). Social Class and School Knowledge. Curriculum Inquiry, 11(1), 3-42. doi:10.2307/1179509

Apple, M. W. (2006). Educating the "right” way: Markets, standards, God, and inequality. New York: Routledge.

Arao, B., \& Clemens, K. (2013). From safe spaces to brave spaces: A new way to frame dialogue around diversity and social justice. In L.M. Landreman (Ed.), The Art of Effective

Facilitation: Reflections From Social Justice Educators. Sterling, VA: ACPA and Stylus Publishing, LLC. 
Au, W. (2016). Meritocracy 2.0: High-Stakes, Standardized Testing as a Racial Project of Neoliberal Multiculturalism. Educational Policy, 30(1), 39-62. https://doi.org/10.1177/0895904815614916

Babulski, T. D. (2017). Disrupting authority: The phenomenality of antioppressive education in the arts (Doctoral dissertation). Available from ProQuest Dissertations and Theses database. (UMI No. 10286503)

Baudrillard, J., \& Guillaume, M. (2008). Radical alterity. Los Angeles, CA: Semiotext(e).

Blocher, J. (2008). Institutions in the marketplace of ideas. Duke Law Journal, 57(4), 821-888.

Capper, C. A., \& Jamison, M.T. (1993). Outcomes-Based Education Reexamined: From Structural Functionalism to Poststructuralism. Educational Policy, 7(4), 427-446.

Carson, C., Huelskamp, R., \& Woodall, T. (1993). Perspectives on education in America: An annotated briefing, April 1992. The Journal of Educational Research, 86(5), 259-310.

Deleuze, G. (1992). Postscript on the Societies of Control. October, 59, 3-7.

Deleuze, G., \& Guattari, F. (1987). A thousand plateaus: Capitalism and schizophrenia (B. Massumi Trans.). New York: Continuum.

Doyle, S. (2007). Member checking with older women: A framework for negotiating meaning. Health Care for Women International, 28(10), 888-908. doi:10.1080/07399330701615325

Ellsworth, E. (1989). Why doesn't this feel empowering? Working through the repressive myths of critical pedagogy. Harvard Educational Review, 59(3), 297-324.

Ellsworth, E. (1992). Teaching to support unassimilated difference. The Radical Teacher, 42(42), 4-9.

Foucault, M. (1990). History of sexuality, vol. 1: An introduction. New York: Vintage.

Freire, P. (2000). Pedagogy of the oppressed (30th anniversary ed., M.B. Ramos Trans.). New York: Continuum. (Original work published 1970)

Giroux, H. A. (1981). Ideology, culture, \& the process of schooling. Philadelphia: Temple University Press.

Gramsci, A. (2011). Prison notebooks. (J. A. Buttigieg, Trans.). New York: Columbia University Press.

Harkavy, I. (2006). The role of universities in advancing citizenship and social justice in the 21 st century. Education, Citizenship and Social Justice, 1(1), 5-37. 
Heidegger, M. (2008). Being and time (J. Macquarrie \& E. Robinson, Trans.). New York: Harper. Perennial/Modern Thought. (Original work published 1927)

Hofsess, B. (2016). Unfolding afterglow: Letters and conversations on teacher renewal. Rotterdam: Sense Publishers.

Hursh, D. (2008), High-stakes testing and the decline of teaching and learning: The real crisis in education. Lanham, MD: Rowman and Littlefield.

Ingber, S. (1984). The marketplace of ideas: a legitimizing myth. Duke Law Journal, 1984(1), 191.

Kalogrides, D. \& Loeb, S. (2013). Different teachers, different peers: The magnitude of student sorting within schools. Educational Researcher, 42(6), 304-316.

Leyva, R. (2009). No Child Left Behind: A Neoliberal repackaging of social darwinism. Journal for Critical Education Policy Studies, 7(1), 365-381.

Littler, J. (2013). Meritocracy as plutocracy: The marketising of 'Equality' under neoliberalism. New Formations, 80(80), 52-72.

McClaren, P., \& Farahmandpur, R. (2006). Pedagogy of Oppression: A Brief Look at No Child Left Behind. Monthly Review, 58(3). Retrieved from http://monthlyreview.org/2006/07/01/the-pedagogy-of-oppression-a-brief-look-at-nochild-left-behind/

Moran, D., \& Mooney, T. (Eds.). (2002). Routledge phenomenology reader. London: Routledge.

National Commission on Excellence in Education. (1983). A nation at risk: The imperative for educational reform. Washington, D.C.: United States Department of Education.

No Child Left Behind Act of 2001, Pub. L. No. 107-110, 115 Stat. 1425 (2002).

Oakes, J. (1986a). Keeping track: The policy and practice of curriculum inequality. Phi Delta Kappan, 68(1), 12-17.

Oakes, J. (1986b). Keeping track, Part 2: Curriculum inequality and school reform. Phi Delta Kappan, 68(2), 148-154.

Pendakur, S. L. (2016). Empowering agents: Developing staff and faculty to support students at the margins. In V. Pendakur (Ed.) Closing the opportunity gap: Identity-conscious strategies for retention and student success. Sterling, VA: Stylus Publishing, LLC.

Peters, C. (1982, September 5). A neo-liberal's manifesto. The Washington Post. Retrieved from http://www.washingtonpost.com 
Pirie, M. (2017). The neoliberal mind. Retrieved from https://static1.squarespace.com/static/56eddde762cd9413e151ac92/t/58e3c27b2e69cf75e 8b510fc/1491321484029/the_neoliberal_mind_web.pdf

Rakoczy, H. (2017). The development of collective intentionality. The Routledge Handbook of Collective Intentionality. London: Routledge.

Spady, W. G., \& Marshall, K. J. (1991). Beyond traditional outcome-based education. Educational Leadership, 49(2), 67-72.

Taylor, B. P. (2010). Horace Mann's troubling legacy: The education of democratic citizens. Lawrence, KS: University Press of Kansas.

Vagle, M. D. (2018). Crafting phenomenological research (2nd ed.). New York, NY: Routledge. 